\title{
A NEMEK EGYENLŐSÉGÉNEK ÉRVÉNYESÜLÉSE A FOGLALKOZTATÁSPOLITIKAI ESZKÖZTÁRBAN, AZ ADÓ- ÉS TB-RENDSZEREKBEN, ÉS HATÁSUK A NŐK FOGLALKOZTATÁSÁRA
}

Az adó- és tb-rendszerek közvetlenül hatnak a jövedelemeloszlásra és a társadalom tagjainak a jólétére, a gyermekvállalásra, oktatásban való részvételére és az élet számos más fontos vetületére is. Az állástalanok és az inaktívak visszavezetését a munkaerốpiacra pedig aktív foglalkoztatáspolitikai eszközök támogatják. Meszsze nyúló következményei miatt hihetetlenül bonyolult feladat a nemek egyenlóségének érvényesítése e területeken, sốt vannak olyan hatásai is, amelyek elốre nem ismerhetók fel, s ebben az összefüggésben utólag nehezen értelmezhetốk. 2010 elején a Szociális és Munkaügyi Minisztérium számára készített kutatás során - hiánypótló jelleggel - a nemek egyenlósége és a nók munkavállalásának ösztönzése szempontjából a munkaeró-piaci eszközöket, az adórendszereket, az egészségügyi és nyugdijjrendszert, valamint a szociális ellátásokat vizsgálták. A kutatás során két horizontális vizsgálat is megvalósult: az egyik témája az egyes témaköröket, részkérdéseket illetố nemzetközi tapasztalatok és elméletek, a másiké a jogi vonatkozások feldolgozása volt. ${ }^{1}$

Kulcsszavak: nemek egyenlósége, gender, foglalkoztatás, foglalkoztatáspolitikai eszközök, adórendszer, nyugdíjrendszer, egészségügyi ellátás, szociális ellátás

Kutatásunk során a nemek egyenlősége és a nốk munkavállalásának ösztönzése szempontjából a munkaerôpiaci eszközöket, az adórendszereket, az egészségügyi és nyugdíjrendszert, valamint a szociális ellátásokat vizsgáltuk. Bár az EU közös célként fogalmazza meg az egyes tagállamok által figyelembe veendő elveket és irányokat, a nagy társadalombiztosítási rendszerek, a különösen a nốk helyzetét befolyásoló családi ellátások, a szociális ellátások - a szubszidiaritás jegyében - az egyes tagállamok döntési és cselekvési szférájába tartoznak.

Megállapíthatjuk, hogy a lakosság nem foglalkoztatott csoportjának helyzetét elsősorban és alapvetően a szociális ellátórendszer különbözó elemei befolyásolják. A nók alacsony - a férfiakénál alacsonyabb foglalkoztatási rátája azt jelenti, hogy a nók gazdasági helyzete bizonytalanabb, mint a férfiaké. A legtöbb EUtagállam integrált megközelítést alkalmaz, kombinálja a családi jövedelemtámogatást (valamennyi család, de különösen az egyedülálló szülők és a nagycsaládok esetében) s a szülók munkaeró-piaci integrálódását elősegítő politikákat.

Arra a kérdésre, hogy Magyarországon a jövedelemadó-, a társadalombiztosítási és szociális ellátórendszerekben, illetve a munkaerópiac passzív és aktív eszközeiben érvényesül-e a nemek egyenlősége, illetve vannak-e bennük gender típusú megközelítések, azt válaszolhatjuk, hogy ha vannak, akkor csak latensen vagy közvetve. Közvetlenül csak elvétve, és akkor is leginkább bizonyos korlátozott számú foglalkoztatáspolitikai eszközök és a szociális ellátások esetében találkozunk, de akkor sem a társadalmi nemekre -, hanem a gyermekes szülókre, és ezen belül is - tradicionálisan - az anyákra, kismamákra vonatkozó speciális megközelítésekkel.

Megállapíthatjuk azt is, hogy a munkaeró-piaci elsősorban az aktív - eszközöket illetően nagyobb te- 
ret kaphatna - mint ahogy több EU-tagállamban kap is - a társadalmi nemek mentén történó tervezés. Az EU-ban alkalmazott aktív eszközök között szerepelnek kimondottan olyanok, amelyek a nók munkaeró-piaci reintegrációját célozzák, Magyarországon ezzel csak elvétve, illetve közvetve - inkább csak horizontális célként - találkozunk. Megjegyezzük, hogy a 2008-as „Közös Jelentés a szociális védelemról és társadalmi befogadásról” címú dokumentum az ,aktív befogadás” elvének három fố pillérét emeli ki:

- híd a munkaerőpiac felé a munkalehetőségeken és szakképzésen keresztül,

- az emberhez méltó élethez szükséges jövedelemszint megteremtése,

- az egyének és családjaik foglalkoztatási reintegrációját és társadalmi befogadását segítố szolgáltatások elérhetôségének javítása (COM(2008) 42 final, 7274/08).

\section{A magyar nók sokat dolgoznak otthon, de alacsony a munkaerố-piaci jelenlétük}

Több vizsgált országgal történő összehasonlításban is szembetúnő, hogy Európában, Olaszország és Észtország után, a szlovén nók mellett a magyar nók dolgoznak a legtöbbet a háztartásban, csaknem kétszer annyi idốt fordítanak háztartási munka végzésére, mint a férfiak. Ugyanakkor kevesebb a szabadidejük és kevesebb idốt töltenek fizetett munkavégzéssel is (Takács, 2008). Ugyanakkor a nók - és persze a férfiak - gazdasági függetlenségének egyik fontos feltétele munkaerő-piaci aktivitásuk. A magyar nók tehát sokat dolgoznak, de sok esetben ez nem jelent számukra gazdasági függetlenséget is, hiszen a háztartásban végzett munka nem jelent munkaeró-piaci aktivitást. Ráadásul a magyar nók olyan szempontból is többet dolgoznak, mint számos uniós társuk, hogy a teljes munkaidős foglalkoztatás hazai dominanciája miatt még annak is nehéz részmunkaidős munkát találni, aki pedig ezt szeretné, vagy képes vállalni az ezzel járó részfizetést.

Magyarországon a 15-64 éves népesség foglalkoztatási rátája általában véve is egyike a legalacsonyabbaknak az Európai Unióban. 2009-ben a 15-64 éves nók kevesebb mint fele - 49,9\%-a - volt jelen a munkaeró-piacon, a férfiaknak pedig 61,2\%-a. Ez azt is jelenti, hogy a helyzet mit sem változott csaknem egy évtized alatt, 2001-ben az e korosztályhoz tartozó nók foglalkoztatási rátája $49,8 \%$, a férfiak $62,9 \%$ volt.

Nem nagy dicsőség, hogy 2001-2008 között Magyarország relatíve alacsony munkanélküliségi rátája „utolérte” az uniós szintet, s különösen gyorsan nőtt a női munkanélküliség, 2004-ben - a rendszerváltás óta elóször-a hazai nói munkanélküliségi ráta $(6,1 \%)$ utolérte, majd 2005-ben már elhagyta a férfiakét is. 2008ban 8,1\%-ra emelkedve a hazai meghaladta az EU-27 7,5\%-os nôi munkanélküliségi rátáját is. A legnehezebb helyzetben a középiskolát - gimnáziumot és szakközépiskolát - végzett 30-44 éves nók vannak, s várhatóan lesznek is a közeljövóben. Az aktív munkaeró-piaci eszközöknek leginkább e korcsoportokra, és ezen iskolázottsági szinttel rendelkezókre kell(ene) irányulniuk.

Mivel a jelenlegi (globális) gazdasági és pénzügyi válság elsősorban a férfi munkaerôt alkalmazó ágazatokban - építőiparban, gépjármúgyártás területén, feldolgozóiparban - éreztette hatását, munkaeró-piaci pozíciójuk kedvezőtlenebbül alakult, mint a nôké. 2010 második negyedévében 22 ezer fővel több nôt foglalkoztattak, mint az elôzô év hasonló időszakában, a férfiakat viszont jelentôs - 39 ezer fốs - létszámcsökkenés jellemezte. Az elbocsátások 2009 második felére gyorsultak fel a legjobban, a munkanélküliek száma ekkor nőtt a leggyorsabban. 2010 második negyedévében a hazai munkanélküliségi ráta $11,2 \%$-ot tett ki, a férfiaké $11,8 \%$-ra, a nóké 10,5\%-ra emelkedett. 2010 második negyedévében ez a tendencia enyhült, s a munkanélküliek száma az elsố negyedévhez képest 25 ezer fővel csökkent (KSH Jelenti, 2010/6.).

Nem segítette a nók munkaeró-piaci integrációját a gyermeknevelés miatti - lehetséges - hosszú távollét sem, amely a munkáltató és munkavállaló közötti kapcsolatot fellazítja. A tapasztalat szerint a távollét hosszával csökken a visszatérés lehetősége, mivel a munkahely megszünik, vagy a munkakör tartalma megváltozik.

Egy korábbi felmérés szerint a gyedról még viszonylag magas arányban lehet visszatérni (88\%-ban), a gyesen, gyeten lévốknél ez az arány már jóval alacsonyabb $(77 \%, 49 \%)$. A nốk munkába állási szándéka a gyermekszám növekedésével arányosan csökken. Vidéken alacsonyabb a munkahelyre visszatérés szándé$\mathrm{ka}$, amelynek hátterében egyrészt a korábban vállalt, de a gyermek mellett már megoldhatatlan utazási nehézségek állnak, továbbá a megfelelố gyermekelhelyezési kapacitások hiánya és/vagy rugalmatlansága. Különösen a községekben - elhelyezkedési lehetôségek hiányában - újabb gyermeknevelési támogatás igénybevételében látják a kiutat, $\mathrm{s}$ ha ez megszúnik, háztartásbelivé válnak. A munkavállalás és a családi kötelezettségek öszszehangolása az igénybe vevő kör csaknem $60 \%$-ának gondot okozna munkába állás során, közülük a túlnyomó többségnek a gyermekfelügyelet megoldatlansága jelenti az elsódleges problémát. Azok körében, akik megfelelő gyermekelhelyezési lehetőség hiányában nem választják a foglalkoztatást, mintegy $90 \%$ igé- 
nyelne segítséget a gyermekfelügyelet megoldásához. Legnagyobb érdeklódés a részmunkaidós és rugalmas foglalkoztatáshoz kapcsolódik (Frey, 2002).

A foglalkoztatási ráta növelésének és a munkanélküliségi ráta csökkentésének egyre erőteljesebben felmerülő célja azt eredményezte, hogy a hangsúly a passzív ellátásról egyre inkább a humánerőforrás-fejlesztéssel kapcsolatos befektetésekre, az aktív munkaeró-piaci eszközök és programok múködtetésére helyeződött. A hazai munkanélküliségi ellátásban és az aktív foglalkoztatáspolitikai eszközökben ${ }^{2}$ bevezetett 2000 -es, 2002-es, 2005-ös, 2007-es, 2009-es változtatások és a 2010-es törekvések célja az volt, hogy a munka nélkül maradót a munkaügyi központtal történő aktív kapcsolattartásra, illetve az álláskeresésre sarkallják.

Az évtized során az aktív foglalkoztatáspolitikai eszközökben résztvevốk átlaglétszáma a kezdeti 103 ezer főról (2000) 65400 főre csökkent (2008). Különösen drasztikus volt a csökkenés 2002-ben, 2004-ben, 2005-ben (csaknem 18\%, illetve 15-15\% az előző évhez képest) (Frey, 2007; Tajti, 2008).

Változott az egyes eszközök által elért személyek megoszlása, folyamatosan csökkent - bár még mindig a legnagyobb tömegeket érint - a közhasznú foglalkoztatás súlya, nốtt a munkaeró-piaci képzéseké és a bértámogatásoké. 2007-2008-ban ez a három eszköz tette ki az aktív foglalkoztatáspolitikai eszközök által támogatottak 90\%-át. (Megemlítjük, hogy Kluve [2006] szerint a közfoglalkoztatási programok nemcsak hogy kevésbé hatásosak, de esetenként hátráltatják a valódi munkaerópiaci integrációt is, továbbá, bár a hagyományos munkaerő-piaci képzési programok hatása pozitív, de nem látványos, s ezeknél 40-50\%-kal eredményesebbek a bértámogatások, illetve az egyéb álláskeresố, pályára segítő programok. Az AFSZ honlapon (www.afsz.hu) megtalálható hazai monitoringvizsgálatok a munkaerôpiaci programok hatékonyságát értékelik a 2005., 2006., 2007. évre vonatkozóan.) Megjegyezzük, hogy 2011ben jelentősen változott a közfoglalkoztatási rendszer, megszűnik a közmunkaprogram, a közcélú munka, valamint a közhasznú munkavégzés, és helyükbe az egységes közfoglalkoztatás lépett. Míg a korábbi „Út a munkához program" százezer közfoglalkoztatottat érintett, 2011-ben kétszázezer fő bevonását tervezik a közfoglalkoztatásba. A korábbi rendelkezésre állási támogatást az ún. bérpótló juttatás váltja fel. Ezt azonban már csak az kaphatja, aki évente legalább 30 nap munkaviszonyt tud igazolni, például úgy, hogy közfoglalkoztatásban vesz részt. Új lehetôségként a vállalkozások foglalkoztathatnak ún. bérpótló juttatásban részesülóket, bár az adósságrendezés alatt álló cégek és önkormányzatok nem pályázhatnak a munkaügyi központhoz bérpótló juttatá- sosok foglalkoztatására. Érzékelhetô azonban, hogy az önkormányzatok által 2011-tốl a csak négy órában történố részmunkaidôs foglalkoztatás a közmunka amúgyis csekély eltartóképességét (és vonzerejét) jelentôsen lerontja (a négy órárt kapott 32 ezer Ft alig valamivel több, mint a 28 ezer Ft ún. bérpótló juttatás).

A mobilitási támogatással, a munkahelymegórzéssel, a munkahelyteremtéssel és a vállalkozóvá válással elértek aránya ezekhez képest elenyésző, bár tendenciájukban különböznek. Az utazási költségtérítésbe részesülő́k aránya csökkenô (2006-2007-ben még 2\%, 2008-ban már csak $1 \%$ volt). Visszaesett a munkahelymegőrzố támogatással elértek aránya is (2006-ban 4\%, 2007-ben és 2008-ban 2\% volt). A vállalkozóvá válás céljából támogatottak aránya viszont nôtt (2006-ban 1\%, 2007-ben 3\%, 2008-ban 4\%). A munkahelyteremtô beruházásokkal elértek aránya 2006-ban 2\%, 2007ben 1\%, 2008-ban viszont „már” 3\% volt.

Az elmúlt években egyértelmú tendencia volt az elfogadott képzések és munkaviszonyban állók képzésének visszaszorulása, s ezzel párhuzamosan az ajánlott képzések és a munkaviszonyban nem állók (ún. elfogadott) képzésének folyamatos térnyerése. Különösen drasztikusan esett az elfogadott képzést befejező 20-34 éves munkanélküli nók száma. Míg az évtized közepén a nók részaránya e képzést tekintve még messze meghaladta a férfiakét, 2007-ben már fordult a helyzet, a férfiaké haladta meg a nôkét. A harmadik, legtöbb embert elérő támogatás, a bértámogatás. Mind 2007-ben és 2008-ban a bértámogatás által érintettek 55\%-a nő volt.

2007-ben a vállalkozóvá válási támogatást igénybe vevốk 56\%-a nô volt, bár 2008-ra ez 51,7\%-ra csökkent. Ez a szám - a némi visszaesés ellenére - azért is figyelemre méltó, mert különböző források szerint a vállalkozó nốk aránya csupán $30 \%$ körüli.

\section{Aktív munkaerố-piaci eszközök: ráfordítások, fajlagos költségek}

Az aktív munkaeró-piaci eszközök részesedése a GDPben uniós összehasonlításban nagyon alacsony, de növekvố tendenciát mutat, 2006-ban ez még csak 0,34\%ot tett ki, 2008-ban viszont már csaknem elérte a GDP fél százalékát. Hasonlóképpen, az aktív eszközök részesedése a teljes Munkaerô-piaci Alap kiadási főöszszegben nőtt, 2006-ban annak még csak 28\%-át tette ki, 2008-ban pedig már 34\%-át, a 2009. évi előirányzatban viszont 27,9\%-ra esett vissza. A passzív kiadások részaránya a Munkaeró-piaci Alap kiadási fóösszegében értelemszerúen csökkent, a 2006. évi 30\%-ról 2008-ra 26\%-ra, 2009-re pedig 24,9\%-ra esett. 2009-re viszont mind az aktív, mind a passzív kifizetések aránya csök- 
kent az összes kiadáson belül, miközben jelentôs mértékben nőttek az ún. egyéb költségvetési befizetések (a 2006. évi 30000 millióról a 2009. évi 101848,70 millió Ft-ra. Ezzel 2009-ben az összes költségvetési befizetés az összes Munkaerô-piaci Alap kiadás csaknem 39\%-át tette ki, a legnagyobb arányú tételt képviselve a kiadásokban. Megjegyezzük, hogy ebból finanszírozták az önkormányzatok az álláskeresók járadékára, segélyére nem jogosult személyek rendszeres szociális segélyét, illetve a részükre szervezett közcélú munkát.

Egy-egy támogatás költséghatékonyságának vizsgálatánál, miután végsố soron valamennyi támogatás esetében a cél a munkaerópiacra történó belépés és a tartós ottmaradás, a követéskor még állásban lévók fajlagos költségeinek vizsgálata valóságosabb képet mutat, mint a pusztán a programokat befejezóké. Nemegyszer jelentốs eltérést kapunk, ha a programokat befejezók és az utánkövetéskor még munkában állók fajlagos támogatását vizsgáljuk. A munkaviszonyban nem állók ún. ajánlott képzésének fajlagos költsége az utánkövetéskor munkában állók esetében 2007-ben csaknem háromszorosa, 2008-ban 2,5-szerese volt a programot befejezettekre eső fajlagos költségnek! 2007-ben és 2008-ban a leginkább költséghatékonynak a munkaviszonyban állók képzése és a vállalkozóvá válás támogatása bizonyult. Ez utóbbi esetében a követéskor és a program befejezésekor vizsgált fajlagos költségek eltérése csupán 13\% (2007), illetve 20\% (2008) volt. A követéskor a havi átlagos fajlagos támogatásokat hasonlítva össze megállapíthatjuk, hogy 2008-ban a „legolcsóbbnak” a pályakezdók munkatapasztalatszerzó támogatása bizonyult (43 215 Ft/fő/hó). 54\%-kal volt drágább a vállalkozóvá válás támogatása (66 $554 \mathrm{Ft} / \mathrm{hó} /$ fő), 38\%-kal többe került a közhasznú foglalkoztatás támogatása $(59569 \mathrm{Ft} /$ fö/hó) és 21\%-kal a bértámogatás (52 527 Ft/fő/hó).
Miután a társadalmi hasznosság objektív mércével történố mérése nehézségekbe ütközik, úgy gondoljuk, hogy egy-egy aktív foglalkoztatáspolitikai eszköz hasznosságának megitéléséhez a fajlagos ráfordításokat és a követéskor munkában lévók arányát együtt vizsgáljuk. Eszerint azt az eszközt tekinthetjük legeredményesebbnek, amely a lehetó legkisebb fajlagos ráfordítás mellett a lehetó legnagyobb arányban tartotta bent a munkaerópiacon az adott munkaeró-piaci programot befejezóket. Elkészítve a legjobb elhelyezkedési aránnyal és a legalacsonyabb fajlagos költséggel jellemzett támogatások rangsorát, és megnézve, hogy e két különbözố szempontból milyen azonos támogatások állnak az elsô három helyen, megállapíthatjuk, hogy 2007-ben mind a nók, mind a férfiak esetében a legjobb elhelyezkedési arány és a legalacsonyabb fajlagos támogatás a vállalkozóvá válást és a pályakezdók foglalkoztatási támogatását jellemezte. 2008-ban viszont - a nók esetében - nem volt olyan támogatás, amely mindkét szempontból az elsố három hely valamelyikén állt volna. 2008-ban már nem múködött a pályakezdôk foglalkoztatási támogatása, viszont a vállalkozóvá válás - bár az elhelyezkedési arányt tekintve a rangsorban az első helyet foglalta el - a fajlagos támogatás nagyságát tekintve túlságosan költségesnek bizonyulva már az 5. helyre szorult vissza. 2008-ban a férfiak esetében a legjobb elhelyezkedési arány és a legalacsonyabb fajlagos támogatás a vállalkozóvá válás támogatását jellemezte. Hozzátesszük, hogy bár az általunk meghatározott kritériumok szerint a pályakezdók foglalkoztatási támogatásai és a vállalkozóvá válás bizonyult leginkább költséghatékonynak, nem ezek az eszközök voltak azok, amelyek számosságában a legtöbb embert elérték. Ez egyrészt a közhasznú foglalkoztatás volt, mind 2007-ben és 2008-ban is több mint 63 ezer fö́t érintve, másrészt a munkába nem állók (ajánlott és elfogadott) képzése (2008-ban több mint 50 ezer fót érintve) (1. és 2. táblázat).

1. táblázat

Aktív foglalkoztatáspolitikai eszközök:

legjobb elhelyezkedési arány és legalacsonyabb fajlagos támogatás szerinti rangsor - nók

\begin{tabular}{|c|l|l|l|l|}
\hline & \multicolumn{2}{|c|}{2007} & \multicolumn{2}{c|}{2008} \\
\hline & \multicolumn{1}{|c|}{ Elhelyezkedési arány } & \multicolumn{1}{|c|}{ Fajlagos támogatás } & Elhelyezkedési arány & \multicolumn{1}{c|}{ Fajlagos támogatás } \\
\hline 1 & $\begin{array}{l}\text { Pályakezdó foglalkozta- } \\
\text { tottak támogatása }\end{array}$ & Munkaviszonyban állók képzése & Vállalkozóvá válás & Pályakezdő foglalkoztat. támogatás \\
\hline 2 & Vállalkozóvá válás & Vállalkozóvá válás & Pályakezdó tapasztalat & Elfogadott képzés \\
\hline 3 & Bértámogatás & Pályakezdó foglalkoztat. támogatás & Bértámogatás & Munkaviszonyban állók képzése \\
\hline 4 & Pályakezdő tapasztalat & Elfogadott képzés & Elfogadott képzés & Bértámogatás \\
\hline 5 & Elfogadott képzés & Bértámogatás & Ajánlott képzés & Vállalkozóvá válás \\
\hline 6 & Ajánlott képzés & Közhasznú munka & & Ajánlott képzés \\
\hline 7 & & Ajánlott képzés & & \\
\hline 8 & & Pályakezdó tapasztalat & & \\
\hline
\end{tabular}

Forrás: saját számítások

\section{VEZETÉSTUDOMÁNY}


Aktív foglalkoztatáspolitikai eszközök:

legjobb elhelyezkedési arány és legalacsonyabb fajlagos támogatás szerinti rangsor - férfiak

\begin{tabular}{|c|l|l|l|l|}
\hline \multirow{2}{*}{} & \multicolumn{2}{|c|}{2007} & \multicolumn{2}{c|}{2008} \\
\cline { 2 - 5 } & \multicolumn{1}{|c|}{ Elhelyezkedési arány } & \multicolumn{1}{c|}{ Fajlagos támogatás } & \multicolumn{1}{c|}{ Elhelyezkedési arány } & \multicolumn{1}{c|}{ Fajlagos támogatás } \\
\hline 1 & Vállalkozóvá válás & $\begin{array}{l}\text { Munkaviszonyban állók } \\
\text { képzése }\end{array}$ & Vállalkozóvá válás & Munkaviszonyban állók képzése \\
\hline 2 & Pályakezdő foglalkoztat. támogatás & Vállalkozóvá válás & Pályakezdó tapasztalat & Vállalkozóvá válás \\
\hline 4 & Pályakezdô tapasztalat & $\begin{array}{l}\text { Pályakezdó foglalkoztat. } \\
\text { támogatás }\end{array}$ & Bértámogatás & Ajánlott képzés \\
\hline 5 & Bértámogatás & Elfogadott képzés & Elfogadott képzés & Bértámogatás \\
\hline 6 & Ajánlott képzés & Bértámogatás & Ajánlott képzés & Elfogadott képzés \\
\hline 7 & & Közhasznú munka & & Pályakezdó tapasztalat \\
\hline 8 & & Ajánlott képzés & & \\
\hline
\end{tabular}

Forrás: saját számítások

\section{Aktív foglalkoztatáspolitikai eszközök: távol a kismamáktól}

1990-2008 között a gyes-, gyed-, gyeten lévók éves szinten mintegy 300-300 ezren voltak. A teljes - a képzésben részt vettek - létszámot vizsgálva, a képzésekben részt vevố sajátos csoportok közül külön is megnézve a gyes-, gyed-, gyeten lévôk részvételét, megállapíthatjuk, hogy számuk elenyészó, 116 fó (közülük 47 fó 2007-ben és 69 fö 2008-ban kezdte meg a képzést).

Feltehetjük a kérdést, hogy mi az oka a képzésben résztvevớk alacsony létszámának, hiszen a gyes-, gyed-, gyeten töltött időszak a késóbbi munkaerópiacra történő visszailleszkedés felkészülésének idôszaka is lehet(ne)? Az okokat keresve - ebben az esetben is - valószínúleg meg kell említeni a napközbeni gyermekellátás gondját, illetve ennek megoldatlanságát egy esetleges képzésben való részvétel során, az információhiányt, a kínálat szúkösségét, a földrajzi távolságot, azaz a képzési kínálat hiányát ésszerú közelségben, esetleg a motiválatlanságot, a tradicionális családmodell által állított akadályokat stb.

Kissé jobb az arány a bértámogatás esetében. 1145 fő - azaz a tárgyévben érintett összes bértámogatásban részesülő 2,8\%-a - volt olyan álláskeresố személy, aki a foglalkoztatást megelőző 12 hónapon belül gyes, gyet, gyed, ápolási díjban, terhességi gyermekágyi segélyben részesült.

A START-programcsaládhoz tartozó, 2007. július elsején elindított START-PLUSZ program célja, hogy támogassa - többek között - a munkaerő-piaci szempontból hátrányos helyzetú kismamák, a kisgyermeket nevelő szülő́k foglalkoztatását. A START-PLUSZ kártyát az indulástól 2009. december 31-ig 36950 fó váltotta ki, közöttük 6277 fô volt a gyes-ról, gyed-ról, gyetrôl visszatérő (SZMM, 2010).

Megemlíthetjük azokat az intézkedéseket is, amelyek a gyermeknevelés idószaka alatt segítik a munkaerô-piaci kapcsolat fenntartását, illetve az anyukák munkába állását, így pl. azt, hogy a gyermek egyéves korától gyes mellett teljes munkaidóben munkát lehetett vállalni. 2011-ben ez a szabály úgy módosult, hogy a gyesen lévố szülő legfeljebb heti 30 órában vállalhat munkát, hacsak a munkavégzés nem a saját otthonában történik. Igaz, ez nem vonatkozik a tartósan beteg vagy súlyosan fogyatékos gyermekek szüleire, akik a gyermek egyéves kora után idốkorlátozás nélkül folytathatnak keresőtevékenységet. Ikergyermekek esetében a gyermekek egyéves kora után szintén időkorlátozás nélkül folytatható keresőtevékenység azzal a feltétellel, hogy a gyermekgondozási segélyben részesülő személy keresốtevékenység folytatása esetén csak egy gyermek után jogosult gyermekgondozási segélyre. (Megjegyezzük, hogy a gyermek hároméves kora elốtt munkát végzố szüloóvel munkáltatói rendes felmondás nem volt közölhetô, amennyiben a munkavégzés mellett gyes folyósításában is részesül. Ez a szabály 2010. május 1-jétól annyiban módosult, hogy a védelem a gyermek három éves koráig akkor is fennáll, ha a szülő nem igényel, vagy nem jogosult gyesre.) A gyes bruttó összegéből 10\% nyugdíjjárulékot vonnak, amely teljes szolgálati idônek minősül. A gyetben részesülő szülő szintén heti 30 órát meg nem haladó időtartamban folytathat keresôtevékenységet, vagy ha a munkavégzés az otthonában történik, akkor idốkorlátozás nélkül. 
Pozitív lépés volt az a rendelkezés is, amely szerint a gyermekgondozás miatt inaktív személyek térítésmentesen szerezhetnek újabb szakképesítést, vagy vehetnek részt felsőfokú képzésben, illetve 2002 óta munkaerôpiaci képzésbe is bekapcsolódhatnak. A probléma viszont az, hogy ezeknek a lehetôségeknek a kihasználtsága nagyon alacsony. Egy további rendelkezés 2005. július 1-jétốl minden 10 ezer fố feletti lakosú településen kötelezôvé tette - az ellátáshoz való hozzáférés javítása érdekében - bölcsôde üzemeltetését, illetve a bölcsődei férôhelyek számának növelését. A gond ebben az esetben is a gyakorlati megvalósulással van, ezt a rendeletet a cső́d szélén álló, illetve a folyamatos forráshiánnyal küszködő önkormányzatok nem tudják betartani, s fél évtized sem volt elég ahhoz, hogy a bölcsődei féróhelyek mennyisége elérje, vagy akár csak megközelítse a keresletet, jelentős akadályt gördítve a munkaerôpiacra ismét belépni óhajtó anyák elé. A helyzeten az idôközben megjelenô új konstrukciók, pl. családi napközi, illetve a borsos árú magánintézmények sem segítenek.

Az anyák - különösen a kismamák - foglalkoztatásánál előnyös foglalkoztatási forma a távmunka és a részmunka. Nem áll azonban rendelkezésünkre adat arról, hogy a - különösen a kismamák foglalkoztatásánál előnyös - részmunka és távmunka elősegítését célzó támogatásoknak milyen specifikus, nôket, illetve kismamákat érintő hatása volt, márpedig - különösen ez utóbbit illetôen - számos projekt indult (legutoljára pl. a Telework Budapest Konzorcium projektje célozta meg mintegy háromezer új távmunkahely létesítését, és 150 rugalmas, távmunkában végezhetố szakma kifejlesztését a TAMOP 1.3.1. program keretében).

Hasonlóképpen nem állnak rendelkezésre nemi bontásban összefoglaló - átfogó - adatok a pályaorientációs, karrier-tanácsadási szolgáltatások igénybevételéról sem. (A TÁMOP 2.2.2. - A pályaorientáció rendszerének tartalmi és módszertani fejlesztése címú kiemelt program - keretében készült ugyan kutatás a pályatanácsadás/életpálya-fejlesztési konzultáció közgazdasági hatásairól, ez azonban elméleti síkon mozog.)

2004-2008-ban „A nók és férfiak egyenlősége” irányvonal megvalósításában a Strukturális Alapok és a Kohéziós Alap által társfinanszírozott több intézkedésnek - HEFOP 1.3., HEFOP 4.2., RFOP 2.3., EQUAL-H - is szerepet szántak. A TÁMOP-projektek horizontális követelményei között találjuk az ún. esélyegyenlőségi vállalásokat. Kérdés, hogy elegendô-e ez a megoldás a gender mainstreaming kellően hatékony érvényre juttatásához, a projektek elkészítói mennyire veszik komolyan e vállalásokat, és mennyire tekintik csupán az adatlap kitöltése során felmerülő formális kötelezettségnek? A TÁMOP Decentralizált programok a hátrá- nyos helyzetúek foglalkoztatásáért 1.1.2. konstrukciója 2008-ban indult, az érintett 20933 fóból viszont mindössze 5,7\% (1185 fó) volt olyan, aki gyermekének gondozását, vagy hozzátartozójának ápolását követôen újrakezdő álláskeresônek minôsüilt. A 2010-ben induló - a gazdasági válság miatt elbocsátásra kerüló munkavállalók munkaerópiacra történő mielóbbi visszasegítését szolgáló - új TÁMOP-programok esetében célszerú lenne a nemek közötti esélyegyenlőség céljainak nem csak a horizontális célkitúzések közötti szerepeltetése, különösen az egyik leginkább kritikus helyzetben lévő réteg, a gyesról, gyedrôl a munkaerópiacra visszatérók esetében. A nemek közötti esélyegyenlőséget nem csupán horizontális célként kezeló program mára már befejeződött, s hosszas viták után végül is folytatásra nem kerülő, EQUAL Közösségi Kezdeményezés volt, aminek keretében több, innovatív program is született. Pl. az EQUAL H/005 BérBarométer létrehozása és múködtetése címú projekt keretében került kifejlesztésre a 10000 fó lekérdezésén (2007/2008) alapuló munkaerô-piaci adatbázis (bérbarométer adatbázis, lásd www.berbarometer.hu), amely lehetővé teszi a fớbb bér- és munkaerô-piaci folyamatok, a munkavállalók objektív munkakörülményei és az ezzel kapcsolatos szubjektív véleményük kutatását nemi bontásban. Az EQUAL-projektek közül pl. az „Újra eséllyel” (E/004) és a „Az esély bölcsődéje” (H/003) a gyermeket vállaló és egy idôre otthon maradó nôk munkaeró-piaci reintegrációjának elősegítését célozta meg. Az EQUAL H/10 „Nő az Esély!”, az EQUAL H/11 „INSPIRÁL” és az EQUAL H/8 „Modellértékú NóTámogató Rendszer" projektek közös célja adott térségekben a munkaerópiacon hátrányos helyzetben lévốk - elsôsorban nốk - munkavállalásának segítése, esélyeinek növelése, a szegregáció csökkentése. Leszögezhetjük, hogy gender szempontból az EQUAL Közösségi Kezdeményezés kiemelkedóen fontos és értékes program volt, ami méltánytalanul - folytatás nélkül - kimúlt. Fontos lenne legalább az e program keretében már kidolgozott, a nók és férfiak gazdasági esélyegyenlőségét is támogató, jelenleg parlagon heveró eszközök listaszerú feltérképezése és hasznosítása!

\section{Néhány javaslat}

A 2000-es években a gyermeket vállaló nók munkaerópiaci integrációjának elősegítése érdekében tett intézkedések sem egyenként, sem együttesen nem bizonyultak elegendônek ahhoz, hogy a nók munkaeró-piaci integrációja javuljon. Érdemes tehát nagyobb figyelmet szentelni az aktív eszközök tervezésénél az utóbbi években a legjobb elhelyezkedési arány és a legalacso- 
nyabb fajlagos támogatás jellemezte támogatásokra, így a vállalkozóvá válásra, a pályakezdốk támogatásaira, valamint az elfogadott képzésre. A különbözó támogatási fajták és aktív eszközök között is kiemelkedik a vállalkozói támogatások hatásának tartóssága. Ennek fényében - a költség-haszon elv alapján - megfontolandó az ilyen típusú támogatások számának nagyságrendekkel történő növelése (természetesen megfelelő igény, kereslet esetén), illetve magának az igénynek a felkeltése is, amely egy hosszú - az iskolában kezdôdő folyamat lehet, a vállalkozási ismeretek oktatásának széles körú elterjesztésével indítva.

Érdemes mélyebben tanulmányozni és esetenként átvenni a külföldi jó példákat. Svájcban pl. újra munkába állásra ösztönöz nagymértékben az, hogy ha valaki elveszti az állását, $\mathrm{s}$ a korábbinál rosszabbul fizetôt talál csak, olyat, ami keresetének a korábbi kétharmadát sem éri el, akkor az állam kiegészíti a fizetését. 2008ban Belgiumban számos intézkedést hoztak a foglalkoztatási csapdák elkerülhetốsége és a vásárlóeró növelése érdekében. A csak félállásban elhelyezkedni tudó munkanélküliek számára az anyagi ösztönzés nem volt elegendő ahhoz, hogy visszatérjenek a munkához. Ennek a problémának a megoldása végett 2008. július 1-je óta minden munkavállaló jogosult a legmagasabb, 75,43 eurós kiegészítésre, amit korábban csak családfenntartók kaphattak. Emellett a szóban forgó részmunkaidős dolgozók jogosultak munkanélküliségi bónuszra, illetve csökkentett társadalombiztosítási hozzájárulásra. A keresómunka vonzóbbá tétele, a munkanélküliségi ellátmányok és a kereset közötti különbség növelése érdekében nemcsak a munkanélküli ellátmányokat, hanem az alacsony keresetúek jövedelmét is növelték. Az aktív munkaeró-piaci programok lényege pl. Németországban az idôsebb munkavállalók - amúgy alacsony - munkaerô-piaci szereplésének fellendítése képzési programokkal, a szakképzésról és a szakképzett dolgozók elhelyezkedéséról szóló nemzeti paktum segítségével a fiatalok képzési és foglalkoztatási kilátásai javulnak. Hollandiában a támogatás kritériuma, hogy valós foglalkoztatásra épüljön: a dolgozó valóban megüresedett helyet vagy új munkakört töltsön be, ami egy év után is biztosítja foglalkoztatását. Nagy-Britanniában 2009 áprilisától az ún. Rugalmas New Deal (Flexible New Deal) lépett a korábbi foglalkoztatási programok helyébe, a korábbiaknál sokkal inkább személyes, egyénre szabott, munkaközpontú megközelítést alkalmazva, beleértve a képességfejlesztést, a munka előtti gyakornoki képzést, mindenkinek az egyéni szükségleteire és a helyi munkaerő-piaci keresletre szabva. Egy további elem az emberek támogatása abban, hogy megmaradjanak a munkahelyükön.
Ennek egyik fontos momentuma az emberek egészségi állapotának javítása. Becslések szerint a rossz egészségi állapot miatt munkájukat elveszítók évente százmilliárd fontba kerülnek. Ennek céljából dolgozták ki a „Fit for Work” támogató szolgáltatást a betegség korai szakaszában lévốk támogatására.

A pontos kép ismeretében konkrét javaslatokat kellene tenni kimondottan a kismamák részmunkaidôs, illetve távmunkában való foglalkoztatására. (Mindenesetre ajánlatos leszögezni, a nói foglalkoztatás ösztönzése során nem szabad kényszert alkalmazni, meg kell hagyni a szabad választás lehetôségét.) A már említett intézkedések mellett (gyes folyósitása munkavégzés mellett) továbbra is napirenden maradt a gyermekgondozásra fordított idó pénzben kifejezett értékének növelése, mivel csak ekkor válhat mérlegelés tárgyává, illetve követelménnyé, hogy mindkét szüló vállalja a háztartási és gyermekellátási munkák terheit, illetve a részmunkaidós foglalkoztatást. Továbbá közelebb vinne a megoldáshoz a közvetett diszkrimináció tilalmának jogszabályba foglalása, illetve a munkabér/ fizetés nagyságának a munkavégzés hatékonyságához és nem a munkaidó tartamához való rendelése. A részmunkaidős foglalkozások bérkalkulációjánál, gyermeknevelés, idôs- és beteg-gondozás esetén magasabb jövedelem járna, a különbség a költségvetésbő́l erre elkülönített keretból jutna a munkavállalóhoz. Fontos lenne, hogy a gender budgeting szemlélet áthassa a munkaerópiac változásait, megakadályozva a nemek közötti egyenlőtlenségek újratermelődését. A fenti intézkedések amellett, hogy csökkentenék a nốk családi/ háztartási feladatokkal kapcsolatos megterhelését, pozitív hatást gyakorolnának a gyermekvállalási kedvre is. Csökkenne - továbbá - a nốknek a túlterheltségükbôl fakadó egészségügyi kockázatuk is.

A gyes-, gyed-, gyeten lévốk munkaerô-piaci képzésben való részvétele elenyésző. Különösen alacsony az ajánlott képzésekben résztvevók száma. Az okokat keresve egyebek mellett valószínúleg beleütközünk az információhiányba, a napközbeni gyermekellátás megoldatlanságába, az utazásba, vagy a kínálat szúkösségébe. A probléma átfogó megoldásához a gyermektámogatási rendszerek és az aktív foglalkoztatáspolitikai eszközök együttes átgondolására, átalakítására van szükség. A képzéssel, szakképzéssel azonban nem szabad megvárni a gyes lejártát, hanem el kellene érni, hogy a gyesról visszatérni szándékozó anyuka képzésen, szakképzésen, vagy egyfajta készségfejlesztési és visszafoglalkoztatási, asszertivitási tréningen vegyen részt. A tréning, amellett, hogy oldja a hosszú távollét miatti szorongásokat, alkalmas lehet arra, hogy egyfajta megfelelő átmenetet biztosítson a munka világába. 
Lépéseket kell tenni a kismamáknak az eddigieknél nagyságrendekkel nagyobb mértékben történô bevonására a már meglévô programokba is, vagy hasonló, pl. az EQUAL innovatív közösségi kezdeményezések által már kidolgozott programok alkalmazásával újakba. (Jó és követendô példaként lásd az EQUAL „Újra eséllyel” (E/004) mintaprojektjét, melynek során a gyes-, gyed-, gyeten lévő ápolónő́k szakmai továbbképzését és a velük való kapcsolattartást valósították meg, megfelelő speciális tananyagot fejlesztve ki, valamint a képzés ideje alatt gondoskodva a gyerekek ellátásáról).

A kisgyermekes anyák munkába állásának egyik sokat, de nem eleget emlegetett - lényeges akadálya a gyermekintézmények elégtelensége. A bölcsődei férôhelyek számának számottevő (s nem csak ígért) növelése jelentősen elősegíthetné a kismamák újra munkába állását. A megfizethetô és minőségi ellátást nyújtó gyermekintézmények hiánya viszont az anyák munkaerô-piaci reintegrációjának komoly akadályát képezi. Az EU a foglalkoztatási stratégiájának megvalósulását, és ezen belül is a nók és az anyák, illetve a fiatal szüloók munkaeró-piaci (újra) belépését célozza a gyermekintézmények felvevôképességének ún. barcelonai célja. Eszerint 2010-ig eló kell segíteni a 3-6 éves gyermekek 90\%-át és a 3 éves kor alatti gyermekek legalább 33\%át befogadni képes intézmények létrehozását. Az Európai Bizottság 2008 végi jelentése (COM[2008] 638 final) vizsgálja a gyermekintézményekkel kapcsolatos barcelonai célkitûzés megvalósulását. Eszerint a 0-3 éves korcsoportnál csak öt EU-tagállamban - Dániában, Hollandiában, Svédországban, Belgiumban és Spanyolországban - érték el a 33\%-os lefedettségi arányt. Nyolc tagállam - legalábbis 2008-ban - 10\%-os, vagy az alatti lefedettségével még messze járt a céltól. Ebbe a csoportba tartozik Magyarország is. A kormány ezzel kapcsolatos ambiciózus bölcsődeépítési programja mindenképpen üdvözlendő (2012-ig 15 ezer férőhely), de a jelenleg rendelkezésre álló kapacitás kétháromszorosára, vagy ennél magasabb féróhelyszámra is szükség lenne a megfelelő lefedettség biztosítása érdekében.

\section{Az adórendszerek gender hatása}

Az EU-ban az adórendszerek - ilyen vagy olyan módon - akár adójóváírással, adókedvezménnyel, akár más módon, figyelembe veszik a családi körülményeket, az eltartottak - a családban nevelt gyermekek - számát. Magyarországon is léteznek a családi kedvezmények, sốt azt mondhatjuk, hogy ezek kivételével napjainkra nagymértékben összezsugorodtak az összevont adóalap adóját csökkentő kedvezmények.
Míg a munkaerópiac eltartóképessége, új munkahelyek létrejötte, azaz a munkaeró-piaci kereslet nagymértékben az aktuális konjunktúra és a vállalkozók döntéseinek függvénye, a munkaerốpiacon való megjelenés az egyének döntésén alapszik. A kormányzatok ezt a döntést ilyen vagy olyan eszközzel ösztönözhetik vagy hátráltathatják. Például a Nagy-Britanniában 2003-ban bevezetett adókedvezmények hozzájárultak a gyermekszegénység enyhüléséhez (ami 1997-ben, amikor a Munkáspárt hivatalba lépett, még a legmagasabbak között volt Európában), illetve elósegítették a foglalkoztatás növekedését is, különösen az egyedülálló szülók munkába állását. A sokat emlegetett családi adózás viszont - a tapasztalatok szerint - nem kedvez a munkába állásnak. A házastársak jövedelmének öszszevonása ellentmond az EK 1980-as években kibontakozott, a férj és feleség ,független adózására” való törekvésének is, s leginkább a konzervatív pártok támogatását élvezi. A családi adózás tiszta rendszerében, ahol az adó alanya az egyes személyek helyett a család, a rendszer leginkább a gyermekvállalást hivatott támogatni az adórendszeren keresztül. Valójában általában az olyan családoknak jó, ahol az egyik félnek magas a jövedelme, a másik pedig nem keres, ahol a nók otthon maradnak gyermeküket nevelni, azaz nem ösztönöz a második keresó munkába állására. A német rendszerben kimutatták, hogy ahogy nó a második keresó részesedése a családi összjövedelemben, úgy csökken a családi adózásból fakadó elóny. (Ez természetes, mert az elóny abból származik, hogy a magas jövedelem összevonva az alacsonnyal, alacsonyabb adókulccsal adózik). A tiszta családi adózást folytató Franciaországban a nók foglalkoztatási rátája megegyezik az EU-15 átlagértékével (60,4\%), és jóval meghaladja akár a magyar, akár más - nem családi adózást alkalmazó - országokét, valamint - Irország mellett - itt a legnagyobb a szülési kedv is. Megjegyezzük, hogy Magyarországon eddig is többször - leginkább politikai vitákban - felmerült a családi adózás gondolata. Ennek a részletei azonban nem kerültek kidolgozásra (még az a kérdés sem tisztázott, hogy hol húzódnak a család határai adózás szempontjából), így várható hatása a nók társadalmi szerepére nem is volt vizsgálható. Ráadásul Magyarországon (is) folyamatosan csökken a házasságkötések, újraházasodások száma, az élettársi kapcsolatban élốk háztartásának közel felében gyermeket is nevelnek. Ugyanakkor Magyarországon a háztartások csaknem 30\%-a egyszemélyes, az egyedül élők kétharmada pedig nô.

A több kelet-európai országban a progresszív adózást legújabban felváltó egykulcsos adózás bár egyszerü, áttekinthetố és hasznos is lehet a gazdasági növe- 
kedés szempontjából, a tapasztalatok szerint a szociális feszültségeket erósitit. Az is elófordult - mint pl. Csehországban -, hogy a legkisebb jövedelmúek a korábbi adókulcsukhoz képest magasabb adókulccsal lettek kénytelenek adózni, azaz messzemenóen igazságtalan volt. A $z$ egykulcsos rendszerben viszont a felsó adókulcsok csökkenése ellenére is a teljes adóbevétel növekedhet.

Áttekintve a legfontosabb hazai adónemeket és azok közelmúltbeli változásait megállapítható, hogy az adóknak közvetlen gender hatása nincs. Az adórendszerek önmagában természetesen nem hordoznak nemi elóitéleteket. Nem irányulnak szándékoltan sem a nốk helyzetének javítására, sem az ellenkezôjére. Hatásuk a társadalomban éló nókre elsósorban a nók keresetén és annak jellegzetességein keresztül jelenik meg.

Közvetett gender hatás persze érzékelhetó, de ez elsôsorban azon keresztül hat, hogy a nók munkaerópiaci részvétele a férfiakétól eltéró jegyeket mutat, így pl. más a foglalkoztatásuk szakmai szerkezete, mint a férfiaké. Mindez azt is jelenti, hogy a nók közül többen dolgoznak alacsonyabb presztízsú, rosszabbul fizetett munkahelyeken, mint a férfiak közül. Ezért a 2010. évi személyiadó (szja)változások inkább érintik kedvezôtlenül a nóket, mint a férfiakat, mivel kimutatható, hogy a 2010. évi szja-változásokkal az átlag alatt keresók mint amilyenek a nók jelentős része is - nem járnak jól. (2009-es adatok alapján a teljes nói foglalkoztatottak 71\%-a keres a bruttó 200000 forint havi kereset alatti tartományban. A férfiaknál ugyanez az arány $67 \%$.) Számításaink szerint 2010-ben az átlagkereset alatt keresók több adót fizetnek, mint ugyanolyan egyéb körülmények között 2009-ben tették. A minimálbért keresók esetében a veszteség 31 ezer forint volt éves szinten. A helyzet a 2500000 forint éves jövedelemmel rendelkezóknél, vagyis az átlagbért keresóknél fordult meg. 2010-ben a legjobban a 4,5 millió forint keresetüek jártak. A gazdaság teherviselő́képességének határát is figyelembe vevő adócsökkentés viszont elôsegíti a foglalkoztatás, s ezen belül a nói foglalkoztatás növekedését, ami egyúttal az adóalap szélesedését is eredményezi.

A hazai személyi jövedelemadó keretén belül az ún. családi adókedvezmény rendszere 1998-ban került bevezetésre, jelentôsége, súlya a rendszer 2005-ös módosítása során azonban visszaszorult. 2006-tól a gyermekek szja-kedvezménye - a harmadik gyermek kivételével kikerült az szja köréból, ez az összeg teljes mértékben beépítésre került a családi pótlék összegébe. 2011-től a gyermekek nevelésére fordított költségek egy része (ismét) az szja-rendszeren keresztül vehetô igénybe. A 2011. évi adó- és járuléktörvény-módosítások szerint 2011. január 1-jétól nemcsak az egykulcsos, egységesen $16 \%$-os személy jövedelemadó került bevezetésre, hanem a családi adózás is. Témánk szempontjából a legfontosabb változás az, hogy a törvény az elsố gyermek vállalását is támogató, jövedelemkorláthoz nem kötött családi kedvezményt vezet be, ami nem az adóból, hanem az adóalapból vonható le. 2011-ben az öszszevont adóalapból egy és két eltartott esetén 62500 forintot, három eltartottól 206250 forintot lehet eltartottanként havonta levonni. Ez az elsô két gyermek után havi 10000 forint, a háromgyerekeseknél gyermekenként 33000 forint támogatást jelent. A rendszer hibája, hogy csak azok tudnak maradéktalanul élni ezzel a lehetôséggel, akiknek elég magas az adóalapjuk. Igaz, a családi kedvezmény megosztható a házaspárok, illetve az élettársak között.

Kétségtelen, hogy a relatíve magas családi pótlék nem ösztönöz munkavállalásra, viszont komoly foglalkoztatást ösztönző hatása lehet annak, ha a gyermekek nevelésére fordított költségek egy részét az szjarendszeren keresztül lehet igénybe venni. A 2011-ben bevezetett rendszer viszont éppen a legnehezebb helyzetben lévốk - alacsony keresetúek, minimálbéren élók, bérrel nem rendelkezốk, akiknek pedig a legnagyobb szükségük van a támogatásokra - esetében nem hatékony. Esetükben célszerúbb volt a kedvezményeknek a családi pótlékba építése. További megoldásként javasolható a rendszer olyan jellegú bekalibrálása, hogy a levonható kedvezmények nagy része - két gyermek esetében is - levonható legyen akár a minimálbérból (ha napirendre kerülne annak megadóztatása), akár negatív adó formájában lehetne nekik érvényt szerezni. Aki pedig nem fér bele a rendszerbe, annak kiegészítésként járna ez az összeg, illetve segélyként kapná meg. Példaként hozhatjuk fel pl. azt az esetet, amikor Nagy-Britanniában, az 1999-es adóreform alkalmával, sor került az ún. dolgozó családok adójóváírásának alkalmazására (working families tax credit), ami azt jelentette, hogy ha az adókedvezmény meghaladta magát a jövedelemadót, akkor a különbséget az állam finanszírozta, ezt az összeget a családok többletjövedelemként kézhez kapták (negatív adóként). Végsố soron a dolgozó családok adókedvezményével két célt szerettek volna elérni: az egyik az, hogy érje meg dolgozni, a másik a gyermekszegénység enyhítése.

\section{A szociális ellátórendszer hatása}

A szociális ellátórendszerek ellátásainak célja a szegénység kockázatának csökkentése, ezen belül is különösen a gyermekszegénység kezelése, az egyedülálló szülő́k támogatása, aki jellemzóen az anya. Az EU Bizottság „Megújult elkötelezettség a szociális Európáért" címú nyilatkozatában található adatok sze- 
rint az EU-állampolgárainak 16\%-át (78 millió embert) fenyeget a szegénység kockázata; közöttük is a gyerekek - 19\%-uk - vannak ennek leginkább kitéve. A gyermekszegénység viszont közvetlen kapcsolatban áll a nói szegénységgel és annak megnövekedett kockázatá$v a l$. A nô és a család szegénységének enyhítése egyúttal a gyermekszegénység enyhítését is jelenti. Az európai közös jelentés (Joint Report on Social Protection and Social Inclusion) szerint abból a célból, hogy megfelelô forrásokat biztosítsanak a családoknak, a legtöbb ország integrált megközelítést alkalmaz a szegénység enyhítéséhez, kombinálja a családi jövedelemtámogatást (valamennyi család, de különösen az egyedülálló szülók és a nagycsaládok esetében) s a szülók munkaeró-piaci integrálódását elósegító politikákat. Az elóbb említett közös jelentés szerint valamennyi uniós tagállam ilyen vagy olyan mértékben és formában támogatja a gyermekes háztartások bevételeit. A legtöbb tagállamban a gyermekes családok jövedelmének támogatásában nem elhanyagolható a családi pótlék jellegú juttatás (átlagban a gyermekes háztartások felé irányuló szociális transzferek kb. felét teszi ki). Ide tartoznak $a z$ anyasággal járó jövedelmek, amelyeket meghatározhatnak abszolút értékben, vagy a keresethez viszonyítva, vagy a speciális ellátások olyan nem várt helyzetekben, mint a fogyatékos gyermekek ellátása, az egyedülálló szülő támogatása. A családi juttatások a gyermekek számától és korától is függhetnek. A legtöbb országban $a z$ univerzális és a célzott juttatásokat kombinálják.

A nók munkavállalása, foglalkoztatása szempontjából kiemelt jelentốsége a gyermek születését követô ellátásoknak van (hazánkban a tes, gyed, gyes, gyet), amelyek egyes esetekben kifejezetten hosszú munkaerö-piaci távollétet tesznek lehetôvé. A nem pénzbeli ellátásokon belül jelentốs szerepe van a gyermekelhelyezést biztositó intézményekhez való hozzáférésnek, az ehhez kapcsolódó téritési díjaknak, illetve kedvezményeknek is.

A családtámogatásokra fordított kiadások Magyarországon az elmúlt évtizedekben meglehetôsen hullámzóan alakultak. A GDP \%-ában kifejezve a kiadások éppen a rendszerváltás idején voltak a legmagasabbak (1990-ben 3,9\%), a 1996-os nagyobb kiigazítást (Bokros-csomag) követôen évekig a GDP 1,5-1,7\%-a körül alakultak, 2006-2007-ben 2,1\%-ot, majd 2008-ban 2,2\%-ot tettek ki. A családi pótlék a családtámogatási rendszer pénzbeli ellátásainak legnagyobb tétele, a rendszerváltás körül részesedése közel 80\%-ot tett ki, a 90-es években elszenvedett reálértékvesztése miatt súlya fokozatosan csökkent, 54-60\%-os mértéküre, majd a 2006-os jelentős mértékú emelkedés hatására részaránya ismét 65\%-ra nőtt. A relatíve magas családi pótlék a szociális kiadásokat jelentősen növeli, viszont ha ennek egy része az szja-n keresztül jut az érintettekhez, nem jelenik meg a szociális kiadások között. Sajnos 2006-tól a gyermekek szja-kedvezménye - a harmadik gyermek kivételével - kikerült az szja-körból, ez az összeg teljes mértékben beépítésre került a családi pótlék összegébe.

A gyed, gyes és gyet igénybevételét együttesen vizsgálva két évtized - 1990-2008 - távlatában megállapítható, hogy ezeknek a rendszereknek az igénybevétele összességében mindvégig meglehetôsen stabilan, mintegy 300 ezer fó körül alakult, köztük a gyeden és gyesen lévók mintegy 260 ezren voltak. A gyet igénybevétele éppen akkor kezdett csökkenni, amikor eltörölték az igénybevétel jövedelmi korlátját, az okok nem ismertek, csak találgatni lehet, hogy a foglalkoztatási feltételek javulásával az érintett kör el tudott helyezkedni, így nem volt szüksége a gyet igénybevételére. A gyed 2000-es visszaállításával a korábban egymásra épülő két rendszerelem helyett két, részben párhuzamos rendszer épült ki, az egyik tb-ellátásként, amely ekkortól már nem a gyermek 1,5 éves koráig, hanem kétéves koráig jár (gyed), és a gyes, amit a gyermek hároméves koráig lehetett igénybe venni, 2010-tól kétéves korig. A T/1813-as számú, „Egyes szociális, gyermekvédelmi, családtámogatási, fogyatékosságügyi és foglalkoztatási tárgyú törvények módosításáról” szóló törvényjavaslat 2010. decemberi elfogadásával a 2010. április 30. után született gyerekek szülei visszamenôleg ismét hároméves korig vehetik igénybe a gyest. Ikergyermekek esetében továbbra is a tankötelessé válás évének végéig, a tartósan beteg, súlyosan fogyatékos gyermekek esetében tízéves korig folyósítható a gyermekgondozási segély.

Gyesre az is jogosult, aki korábban nem rendelkezett fizetett munkával, és az is, aki a gyed lejártát követóen nem tudott vagy nem akart elhelyezkedni. A gyermeknevelési ellátás (gyet) 1993-ban indult szintén biztosítási előzményt igénylő ellátásként, amely 1998-ig a gyeshez hasonlóan jövedelemvizsgálathoz kötött ellátás volt, ezt követóen vált alanyi hozzáférésüvé, harmadik és további gyermek nevelése esetén a legkisebb gyermek nyolcéves koráig. A gyes folyósítási idejének visszaállításával összhangban a gyermeknevelési támogatás (gyet) újra a gyermek hároméves korától nyolcéves koráig jár.

A családi kötelezettségek és a munkavállalás összehangolását biztosítandó a gyes és a gyet esetében a kezdetektól lehetóség volt részmunkaidốs foglalkoztatásra, sốt a gyes esetében a késóbbiekben teljes munkaidós foglalkoztatás is megengedett volt, ezzel azonban csak nagyon csekély mértékben éltek az érintettek. A gyes melletti foglalkoztatás mindvégig alacsony volt, és ennek mértéke is tovább csökkent az 1993. havi 6\%-ról a 2005. évi 4\%-ra. 
Azaz a gyes melletti foglalkoztatással kapcsolatos törekvések mind a mai napig hatástalanok maradtak. A tartós, hosszú távollétet a munkaerópiacról a rendszer elemeinek egymásra épülése teszi lehetővé, amely a gyes felé nyitott, így a gyermek hároméves koráig biztosítja a fizetett távollétet. Magyarországon kiugró eltérések tapasztalhatók a kisgyermekes és többgyermekes nôk foglalkoztatási rátáiban, mind a többi korosztályhoz viszonyítva, mind pedig nemzetközi öszszehasonlításban. Ez valószínúleg összefügg azzal is, hogy Magyarországon nemzetközi összehasonlításban is magas a gyermeknevelést támogató ellátórendszerek igénybevétele és hosszú ideig fizetik a kisgyermekes szülő́k távollétét a munkaerôpiactól.

Az EU-tagállamok közül Magyarországon a legalacsonyabb a kétévesnél kisebb gyerekeket nevelő anyák foglalkoztatási szintje, a három és öt év közötti gyereket nevelók közt pedig a második legalacsonyabb. A gyermek napközbeni elhelyezkedését segítő infrastruktúra továbbfejlesztése nélkül azonban érdemi áttörés nem következhet be, s lényeges a szülő́k képzését, elhelyezkedési esélyeit javító programok indítása.

Végső soron megállapítható az is, hogy az egyén választási lehetóségét messzemenóen korlátozza az a gyakorlat, amely egy olyan rendszerre épül, amelynek egyes elemei eredendôen abból a célból kerültek bevezetésre, hogy az otthonlét pénzügyi támogatását biztosítsa. Ez a helyzet mára gyökeresen megváltozott, amikor állások, munkahelyek tünnek el néhány év alatt. Abban az esetben, ha a munkahely megszúnt, felszámolták, még a legerôteljesebb eszközökkel, bírósági kötelezés mellett sem kényszeríthetô ki az, hogy valakit a korábbi állásába helyezzenek vissza, különösen, ha az már régen nem létezik. A gond az, hogy a megváltozott körülmények közepette a rendszer mára olyan formában múködik, hogy választásra kényszerít a gyermeknevelés és a munkavállalás között, nem teszi lehetővé ezeknek a szerepeknek a kiegyensúlyozott, de legalábbis konfliktusmentes egymás melletti múködését. Mindez azt jelzi, hogy a rendszer ebben a formában nem is segíti és alkalmatlan is a két szerepkör harmonikus múködésének támogatására. Viszont az azonnali szigorítás sem megfelelő megoldás olyan idôkben, amikor a munkanélküliségi ráta hónapról hónapra kúszik felfelé, mert nem lenne célszerú lépés a hozzáférés drasztikus szigorításával a munkanélküliek számát tovább növelni. Ráadásul a gyermekelhelyezést biztosító intézményrendszer, a bölcsőde, a gyed feltételeinek kiterjesztésével párhuzamosan drasztikusan leépült, a bevezetést követő húsz évben kevesebb mint felére esett vissza. Pillanatnyilag tehát sem munkaerő-piaci oldalról nincsenek meg a megfelelő feltételek, sem pedig a szükséges gyermekelhelyezési kapacitások nem állnak rendelkezésre a helyzet gyors megváltoztatásához, s a megfelelő intézményi háttér, gyermekelhelyezési lehetőségek hiányában egyéni szinten sincs többnyire lehetôség érdemi választásra a gyermeknevelés és a munkavállalás között, azaz tulajdonképpen egy csapdahelyzet alakult ki. Olyan keretek kidolgozására van szükség, amely kiküszöböli a „ha nem veszem igénybe, akkor végleg elvész a számomra" típusú döntési kényszert. Ezt a megoldást ki kell, hogy egészítse egy rugalmas, differenciált igényeket kiszolgálni képes, megfizethetô gyermekelhelyezési infrastruktúra, és olyan rugalmas munkaszervezet, amely lehetôvé teszi, hogy a nók életébe a foglalkoztatás mellett a családi kötelezettségek többletterheinek ellátása megfelelő módon beilleszthetô legyen. Bár ezt nem lehet szabályozással, rendeletekkel elérni, mégis kampányok, különféle támogatási hidak, elsősorban a közszférában bevezetendő példaadó gyakorlatok elterjesztése, propagálása révén középtávon elérhetố egyfajta kulturális áthangolódás, a berögzült gyakorlatok áttörése.

A munkaerô-piaci megfontolások mellett a rendszer átalakításánál mindvégig célszerú szem előtt tartani, hogy a gyermektámogatási rendszerek múködése, megváltoztatása nagyon érzékeny területeket érint és kapcsol össze, ahol különféle szempontok, sokszor számos mögöttes értékrend is megmérkőzik (vagy alkalmasint megütközik). Ezeknek a rendszereknek a kétségtelenül szükséges átalakítása csak abban az esetben lehet hatékony, ha értékmentesen, széles körú választási lehetốségek biztosításával viszonyul a kérdéshez, megfelelő alternatívákat felkínálva biztosítja a kívánt foglalkoztatáspolitikai célkitűzések elérését. A kulcsszó a kölcsönös alkalmazkodás, a rugalmasság és informáltság lehet, továbbá le kell számolni azzal az illúzióval, hogy rövid átmenet mellett ,át lehet állítani a váltót”. A korábban bevezetett gyermektámogatási rendszerek melletti foglalkoztatást ösztönző kezdeményezések kudarcai is arra figyelmeztetnek, hogy azonnali áttörés ezen a területen nem várható, de annál hatásosabb lehet egy hosszabb átmenetet biztosító áthangolási akció, amely azzal az előnnyel is járhat, hogy kiküszöböli az esetleges hektikus oda-vissza reakciókat a rendszer feltételeinek alakításában.

\section{A nyugdíjrendszer hatása}

A nyugdíjakkal kapcsolatos kedvezmények nem a társadalmi nemekkel vannak kapcsolatban, hanem a nyugdíj eltartóképességével. A nók nyugdíja viszont alacsonyabb, mint a férfiaké, köszönhetően az alacsonyabb életkeresetnek, a nók és a férfiak közötti bérdifferenciának az aktív életük során, a nốk esetében a 
keresôtevékenységgel eltöltött kevesebb aktív évnek. Sơt, ha úgy vesszük, a nemek közötti egyenlő bánásmód és diszkriminációmentesség megvalósításában a hazai társadalombiztosítási nyugdíjrendszer komoly eredményeket könyvelhet el, mivel olyan újraelosztási mechanizmusokat múködtet, amelyek a férfiak és a nôk között aktív életkorban fennálló kereseti különbségeket jelentôs mértékben mérséklik. A magyar nyugdíjrendszer a nemeknek jogegyenlóséget biztosit, ennek feltételei fokozatosan alakultak ki (férfiak is jogosultak özvegyi nyugdíjra, gyermeknevelési ellátásokra). A különféle gyermeknevelési, gyermekgondozási formák, ápolási idốk szolgálati idốbe történő beszámítása, - amelyet elsôsorban nôk vesznek igénybe - szintén a nemek esélyegyenlőségét elősegítő tényezô.

Egy további, szintén a nemek közötti egyenlőséget javító tényezố az, hogy az idôsebb korban fennálló demográfiai különbségeket a nyugdíjrendszer megfelelóen kompenzálja (ennyivel tovább folyósít a nôknek nyugdíjat, miközben a hozzáférési szabályokban nem tesz különbséget). Sót, a kötelező rendszer második (tókefedezeti) pillérében szabályozás írja elő az unisex ráták alkalmazását, azaz az ellátások kiszámításánál a pénztár nem veheti figyelembe a nemek közötti demográfiai eltéréseket. Enélkül a nók számára folyósított járadék jóval elmaradna a férfiakétól. A kalkulált járadékösszegek ugyanolyan befizetések mellett nem térhetnek el aszerint, hogy nô (és ezért évekkel tovább él), vagy férfi-e az illetô. Megjegyezzük, hogy az egyéni számlán felhalmozott összeget a felhalmozási periódusban a kedvezményezett (feleség, élettárs, szülő, gyerek, illetve bárki számára, akit a pénztártag kedvezményezettként megjelölt) örökölheti, saját számlájára írathatja, de a kifizetési periódusban ez már nem érvényesíthetô.

Mindemellett azonban érdemes megfontolni - sốt elkerülhetetlen - a gyermeknevelés honorálásának, további preferenciáinak megerősítését a nyugdíjrendszerben. Azokra a kohorszokra, akik nem részesülnek a korhatár- és elörehozott nyugdíjkedvezményekben, és már a magasabb korhatáron mehetnek nyugdíjba, ezt a munkát a nyugdíjreformok során el kell végezni. A részmunkaidôs és atipikus foglalkoztatás elterjedése során szükség van a nyugdíjrendszer általi korrekt kezelésükre.

Folyamatosan monitorozni kell a nyugdíjrendszer nemek egyenlőségére gyakorolt hatását, ezt 2-3 évente át kell tekinteni, mert előre látható, jól prognosztizálható elemek nincsenek. Ennek fontos része kell, hogy legyen az egyéni tipikus nyugdíjpályák modellezése, figyelembe véve a társadalmi nemek egyenlőségének szempontját is.
Egyszeri, és a nôket kedvezô helyzetbe hozó intézkedésnek tekinthetô az, hogy 2010. december 20-án a parlament elfogadta ,A társadalombiztositási nyugellátásról szóló 1997. évi LXXXI. törvény" módositását a nốk kedvezményes nyugdíjba vonulásával kapcsolatban. Eszerint öregségi teljes nyugdíjra életkorától függetlenül jogosult az a nố is, aki legalább negyven év jogosultsági idővel rendelkezik. Megjegyezzük, hogy jogosultsági időnek minősül a keresőtevékenységgel járó biztosítási, vagy azzal egy tekintet alá esố jogviszonnyal, valamint a terhességi-gyermekágyi segélyben, gyermekgondozási díjban, gyermekgondozási segélyben, gyermeknevelési támogatásban és a súlyosan fogyatékos vér szerinti vagy örökbe fogadott gyermekére tekintettel megállapított ápolási díjban eltöltött idővel szerzett szolgálati idő.

\section{Az egészségügyi ellátórendszer hatása}

$\mathrm{Az}$ EU-tagállamokban az egészséggel kapcsolatos egyenlőtlenségek gazdasági-társadalmi csoportonként jól megfigyelhetók. Ennek jó mutatója a születéskor várható átlagélettartam és az egészségesen leért életévek nemek közötti különbségei. Mivel ezeket jelentôs mértékben befolyásolják egy-egy ország iskolázottsági, foglalkozási és jövedelmi viszonyai, ezért csak azok a megállapítások relevánsak, hogy minden országban magasabb a születéskor várható átlagélettartam a nốk javára, és az országok közötti szórás is kisebb, nôknél 8 év, férfiaknál 14 év. Ezzel ellentétes a nők egészségben megélt életéveinek száma, és itt a szórás is nagyobb, mint a férfiaknál (18 év). A nốk az EU-tagállamok átlagában 6 év többlettel rendelkeznek, de egészségben megélt éveik számát a rosszabb egészségi állapotuk jobban veszélyezteti, mint a férfiakét. Megjegyezzük, hogy az egészségi állapotot illetően a legtöbb adatnál nincs nemek szerinti adatbázis, igaz, ennek létrehozását 2012-re tervezik. Az egészséggel kapcsolatos egyenlótlenségek az élet és munkakörülményekhez, az egészséges életmódra való törekvés intenzitásához, illetve az egészségügyi szolgáltatások eléréséhez is kapcsolódnak. Végső soron ahhoz, hogy az egészséggel kapcsolatos egyenlőtlenségek enyhüljenek, a szociális védelem növelésére és a társadalmi kirekesztés különböző fajtáinak megszüntetésére van szükség. Azonban bármilyen típusú egészségügyi modell is jöjjön létre, leszögezhetjük, hogy a mai modern társadalomban a szolidaritási elvnek valamilyen szinten érvényesülnie kell. A szolidaritásra nemcsak a jövedelmi egyenlôtlenségek enyhitése, hanem más - pl. éppen a gender - szempontok miatt is szükség van. Pusztán magánbiztosítással ez a fajta szolida- 
ritás - kelló mélységú jogi szabályozás és szankciók beépítése nélkül - nem tudna megvalósulni. A nôk fogékonyabbak az egészségtudatos magatartásra, mint a férfiak. Az ismeretek és képzettség növekedése a lakosság körében azt eredményezi, hogy a fogyasztók az egészségtudatos megoldásokat választják minden területen. Ideálisnak azt az állapotot tekinthetjük, amikor - az egészségügyi rendszer szerveződésétől függetlenül - az egészség megốrzését „,fóáramként” kezelve és az egészségügyi ellátás középpontjába a prevenciót helyezve, a közvetlen egészségügyi kiadások - vagy növekedésük - lassulnak, miközben a születéskor várható élettartam nő, a lakosság egészségi állapota javul. Ezt az állapotot még csak néhány ország tudja felmutatni, pl. Luxemburg, Dánia, Finnország. A kutatási eredmények jól mutatják, hogy az egyéni tényezóknnek az egészségegyenlőtlenségekben betöltött szerepe döntố mértékben meghatározó. A magyar lakosság egészségének javításához, az egészségegyenlőtlenségek csökkentéséhez elengedhetetlen az egészségügynek más szektorokkal való együttmúködése. A lakosság egészségét leginkább javító beavatkozások célterületei, többek között a foglalkoztatás is, más szektor felségterülete, ezért olyan szakpolitikák alkalmazása javasolható, melyek egészségesebb lakókörnyezet, iskolák, munkahelyek kialakítását célozzák, a nók esetében támogatják a nók választási lehetốségeinek a jelenleginél nagyobb méretékú kiszélesitését, csökkentik az egyenlótlenségeket. Nem lehet elégszer hangsúlyozni az egészségmagatartás, egészségállapot multiszektoralitását sem (oktatás, szociális terület stb.), különösen a nóknél, így kiemelkedó fontosságú ezek támogatása. A megbetegedések csökkentéséhez nagymértékben hozzájárul a szegénység mérséklése a nók körében (özvegyek, gyermeküket egyedül nevelôk, alacsony iskolai végzettségúek, romák támogatása). Az oktatáspolitikai, szociálpolitikai, foglalkoztatáspolitikai lépéseknek ebból adódóan - az egészségpolitikai kezdeményezéseken túl - komoly hatásuk lehet a nók egészségi állapotának javulásában, fontos lenne az ,egészség minden szakpolitikában elv" alkalmazása.

A nốk megbetegedéseinél kiemelt jelentốsége van a stressznek, illetve a folyamatos stresszhatás és az elégtelen megbirkózás miatt kialakuló alacsony koherencia és depressziós tünetek együttjárásának. A stresszforrások között dominánsak a családi konfliktusok, illetve a munkahelyi stressz (ez utóbbi gyakran a családi konfliktusok eredóje, illetve következménye, a két szerep problémás összeegyeztetéséból adódóan). Vagyis a megoldás e stresszhatások csökkentése, a nók segítése az ôket érô kihívások, problémák megoldásá- ban. Az észak-európai országokhoz hasonlóan - akár törvényekkel is alátámasztva - alapvetó attitúdváltozást kellene elérni a lakosság széles rétegein belül, hogy a család ellátása ne nói, hanem szülói, házastársi feladatokként jelenjen meg. Azáltal, hogy a magas képzettségú nók is választási kényszer elốtt álnak: munka vagy család, a konfliktusok jelentốs mentális problémákat okozhatnak. Mivel a gyermekneveléshez kapcsolódó sztereotípiák megakadályozzák a nók férfiakhoz hasonló teljes értékú részvételét a munkavállalásban, vagy csökkent értékú munkaerónek számítanak, vagy a „munka-család” konfliktus nagy lelki megterhelést okoz. Éppen ezért fontos lenne Magyarországon is bevezetni a kötelezóen megosztandó nók és férfiak szülói szabadsághoz való jogát, az anyasági/apasági szabadság gyermekszületés esetén érvényes szabálya$i t$, felhasználva azokat a tapasztalatokat, gyakorlatokat, amelyek a skandináv országban jól beváltak, jelentősen javítva a nốk munkaerô-piaci helyzetét, és ezzel párhuzamosan növelve a nók gyermekvállalási hajlandóságát. Javasoljuk a családi és szakmai élet jobb összeegyeztetésére a gyermek- és egészségnevelési ismeretek bevezetését az alapfokú oktatás felsố tagozatában, legalább négy félévre kiterjesztve, fiúknak-lányoknak azonos ismeretekkel. Intézményesíteni kell - továbbá - a gyermekek és más önmagukat ellátni nem képes személyek gondozását, széles körú nevelési, egészségi ismeretekre alapozva megfizethetô, ellenôrizhetô struktúrák létrehozásával, önkormányzatok felelősségvállalásával és koordinálásával.

\section{Zárszó}

A gender hatásokat vizsgálni csak az aktuális állapot pontos ismeretében lehet. Ha komolyan vesszük azt az európai uniós irányelvet, hogy ennek a kérdésnek a vizsgálatát minden jelentős döntésnél szem előtt kell tartani, akkor ehhez megfelelő részletezettségú, nyilvános adatbázisokat kell biztosítani. Ezek jelenleg nem állnak rendelkezésre. A gazdaságstatisztika a legritkább esetben tartalmazza a nemek szerinti bontást, a háztartásstatisztika sem tartalmaz nemek szerinti megkülönböztetést és a fogyasztási szerkezetet illetően sem állnak rendelkezésre árufócsoportokra vonatkozó nôi és férfi vásárlási táblázatok, nemi bontású fogyasztási panelek. Természetesen ennek hiányában is lehet vizsgálódni. Ekkor azonban minden kutatásnál egyedi adatfelvételt kell végezni, ami jóval költségesebb, és az így összegyújjtött adatok kevésbé összehasonlíthatóak más vizsgálatok eredményeivel, mint ahogy a nyilvános adatbázisok elemzésével nyerhető adatok lennének. 


\section{Lábjegyzet}

${ }^{1}$ A hipotézisekre adott válaszok és a javaslatok, valamint a zárótanulmány - amelyet dr. Borbély Szilvia készített - az alábbi résztanulmányok alapján készültek:

- Borbély Szilvia: Nemek egyenlőségének érvényesülése az adó-, társadalombiztosítási és szociális rendszerekben, hatásuk a nói foglalkoztatásra - Nemzetközi kitekintés

- Borbély Szilvia: Munkanélküli ellátások, aktív munkaerô-piaci politikák gender szempontból

- Lukács Erika: Nemek egyenlőségének érvényesülése a tbrendszerekben és hatásuk a nók foglalkoztatására. Családtámogatások, gyermektámogatási rendszer

- Rózsáné Lupkovics Marianna: Nemek egyenlőségének érvényesülése az adó-, társadalombiztosítási és szociális rendszerekben, hatásuk a női foglalkoztatásra - Jogszabályok, jogi és érdekszempontok bemutatása

- Schadt Mária - Péntek Eszter: Nemek egyenlóségének érvényesülése az egészségügyi ellátások terén, az egészségbiztosítási rendszerekben, és hatásuk a nók foglalkoztatására

- Vanicsek Mária: Az adórendszer értékelése a nemek egyenlósége szempontjából, és hatása a nók foglalkoztatására (szja, áfa, vagyonadó, társasági adó, EVA)

${ }^{2} \mathrm{Az}$ általunk vizsgált aktív foglalkoztatáspolitikai eszközök: munkaerô-piaci képzés; közhasznú foglalkoztatás; foglalkoztatás bővítését szolgáló bértámogatás; munkahelyteremtő beruházás támogatása; álláskeresốk vállalkozóvá válását elősegítő támogatás; munkába járással kapcsolatos utazási költségtérítés; munkahelymegốrzés támogatása; pályakezdók eszközei.

\section{Felhasznált irodalom}

Borbély Sz. (2010): Nemek egyenlőségének érvényesülése az adó-, társadalombiztosítási és szociális rendszerekben, hatásuk a nói foglalkoztatásra - Nemzetközi kitekintés. SEED Alapítvány

Borbély Sz. (2010): Munkanélküli ellátások, aktív munkaerôpiaci politikák gender szempontból. SEED Alapítvány
Frey M. (2007): Aktív munkaerô-piaci eszközök múködésének értékelése 2001-2006 között és változásai 2007-ben; http://www.econ.core.hu/file/download//frey.pdf

Frey M. (2002): A gyermeknevelési támogatásokat igénybe vevő és a családi okból inaktív személyek foglalkoztatásának lehetôségei és akadályai. Összefoglaló a HU991813 PHARE-program keretében végzett statisztikai kutatás zárótanulmánya. Budapest

Kluve, J. (2006): The Effectiveness of European Active Labour Market Policy. IZA Discussion Paper, No. 2018, Bonn

Lukács E. (2010): Nemek egyenlőségének érvényesülése a tb-rendszerekben és hatásuk a nôk foglalkoztatására. Családtámogatások, gyermektámogatási rendszer. SEED Alapítvány

Rózsáné Lupkovics M. (2010): Nemek egyenlőségének érvényesülése az adó-, társadalombiztosítási és szociális rendszerekben, hatásuk a nôi foglalkoztatásra - Jogszabályok, jogi és érdekszempontok bemutatása. SEED Alapítvány

SZMM (2010): ÁFSZ, TÁMOP 1.2.1. - „Hátrányos helyzetúek foglalkoztatását ösztönzô járulékkedvezmények" elnevezésú program ismertetése

Schadt M. - Péntek E. (2010): Nemek egyenlőségének érvényesülése az egészségügyi ellátások terén, az egészségbiztosítási rendszerekben, és hatásuk a nôk foglalkoztatására. SEED Alapítvány

Tajti J. (2008): A foglalkoztatáspolitikai eszközök múködése 2008-ban, FSZH

Vanicsek M. (2010): Az adórendszer értékelése a nemek egyenlősége szempontjából és hatása a nók foglalkoztatására (szja, áfa, vagyonadó, társasági adó, EVA), SEED Alapítvány

Cikk beérkezett: 2010. 6. hó

Lektori vélemény alapján véglegesítve: 2010. 8. hó 